Reprod. Nutr. Dévelop., 1981, 21 (5A), 689-694.

\title{
The effect of age on five ions of the kidney in the Fischer 344 rat
}

\author{
par S. I. BASKIN (1), Kim P. KUHAR, F. J. URICCHIO, G. R. HARPER \\ Department of Pharmacology, Medical College of Pennsylvania \\ 3300 Henry Avenue, Philadelphia, PA 19129, U.S.A.
}

Summary. It was proposed that the diminished renal function observed with advancing age could be due to a lower concentration of essential ions within the organ or an accumulation of ions which could produce cellular toxicity. This investigation reports the effect of age $(3,6,12,24$ and 28 months) on the concentrations of magnesium, calcium, zinc, copper and iron in renal homogenates of Fischer 344 strain rats. Samples of renal tissues were homogenized in a solution containing 5 p. $100 \mathrm{La}+25$ p. $100 \mathrm{HNO}_{3}$. The samples were digested, centrifuged and assayed by atomic absorption spectrophotometry. With age, the magnesium concentration decreased $(P<0.05)$ while the calcium and copper concentrations remained unchanged, and the zinc concentration decreased slightly while the iron concentration markedly increased $(P<0.05)$. In summary, these data and other data obtained from similar studies of the brain and heart, suggest that the changes observed with age are unique to the kidney. Our results suggest that changes in ionic concentration in the kidney with respect to age could contribute to the diminished function observed in that organ with senescence.

\section{Introduction.}

The kidney and its susceptibility to disease undergo alterations with age (Lowenstein, 1979 ; Coleman et al., 1977). Cations are involved with renal metabolism as activating or inhibiting ions of enzymatic reactions (Epstein and Silva, 1974).

For example, iron has been found to change significantly with developmen between the ages of 1 to 4 months in the kidney of the rat (Yunice et al., 1968) ; cadmium and chromium also increase in the kidney with age as demonstrated in a study conducted by Schroeder ef al. (1965). Since our previous studies showed that divalent cations change in other organs of the rat with age, e.g. heart (Baskin ef al., 1979), we undertook a study to determine if age-related differences in the concentrations of five cations in the kidney of the Fischer 344 rat could contribute to the toxicity observed in that organ with age.

\section{Materials and methods.}

Male Fischer 344 rats $(90,180,365,790$ and 840 days old) were raised behind barrier conditions (Coleman et al., 1977) at the Charles River Breeding Laboratories, Inc.

(1) Please address all correspondence to Dr. Steven I. Baskin. 
(Wilmington, Massachusetts, USA). The animals were shipped in special containers to the Medical College of Pennsylvania and housed up to a time equivalent to 10 p. 100 of their age at the time of shipment under specifications outlined by the National Institute of Aging (USA). The animals were sacrificed by decapitation and the kidneys were quickly removed and frozen to $-20^{\circ} \mathrm{C}$, with some of the kidneys remaining frozen for a maximal period of one year. In order to establish the effect of freezing on organs, fresh organs were analyzed and the data obtained were not different $(P<0.05)$ from those of the frozen specimens.

The frozen kidneys were thawed and dissected to remove extraneous material. The tissue was homogenized in 5 p. 100 lanthanum, 25 p. $100 \mathrm{HNO}_{3}$ and digested on a Fischer roto-rack for $48 \mathrm{hrs}$. The final dilution for analysis was $1 \mathrm{p} .100$ lanthanum and 5 p. $100 \mathrm{HNO}_{3}$. This method is similar to that described previously by Baskin et al. (1973). The samples were centrifuged at $100000 \times \mathrm{g}$ for $30 \mathrm{~min}$ to remove the debris and were analyzed on an atomic absorption spectrophotometer (Instrument Laboratories, IL 251). Standard curves were determined daily for each of the ions. The wave lengths $(\mathrm{nm})$ used for the cation analysis were : magnesium at 285.2 ; calcium at 422.7 ; zinc at 213.9 ; iron at 248.3 and copper at 324.7.

The probability level of $P<0.05$ was determined to be significant by the student's t-test (Weiner, 1971).

\section{Results.}

The effect of age on the concentration of renal magnesium is shown in figure 1. A decrease was observed between 90 and 840 days of age. The most marked effect was
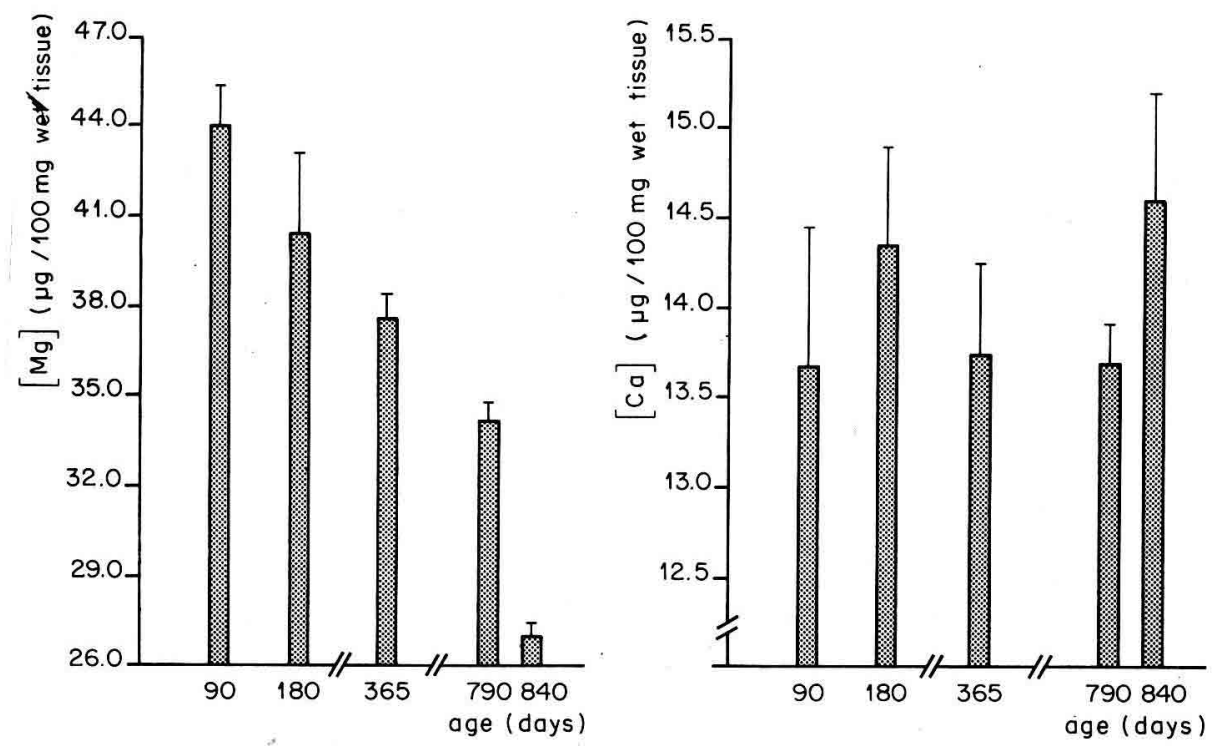

Effect of age on renal ionic concentrotion in the Fischer 344 rat.

FIG. 1. - Magnesium.

FIG. 2. - Calcium. 
between 790 and 840 days of age. This pattern of magnesium diminution observed in the kidney was not found in the heart (Baskin et al., 1979) or brain.

The effect of age on the concentration of renal calcium is shown in figure 2 . No significant change was observed between 90 and 840 days of age. These data are unlike those of brain or heart tissue in which an age-related increase in tissue calcium occurs.

The effect of age on the concentration of renal zinc is shown in figure 3. A significant decrease was observed between 90 and 840 days of age. These data are unlike those observed in the heart (an increase) and the cerebellum (no substantial pattern with age). The largest changes appeared to occur at the youngest and oldest ages examined.
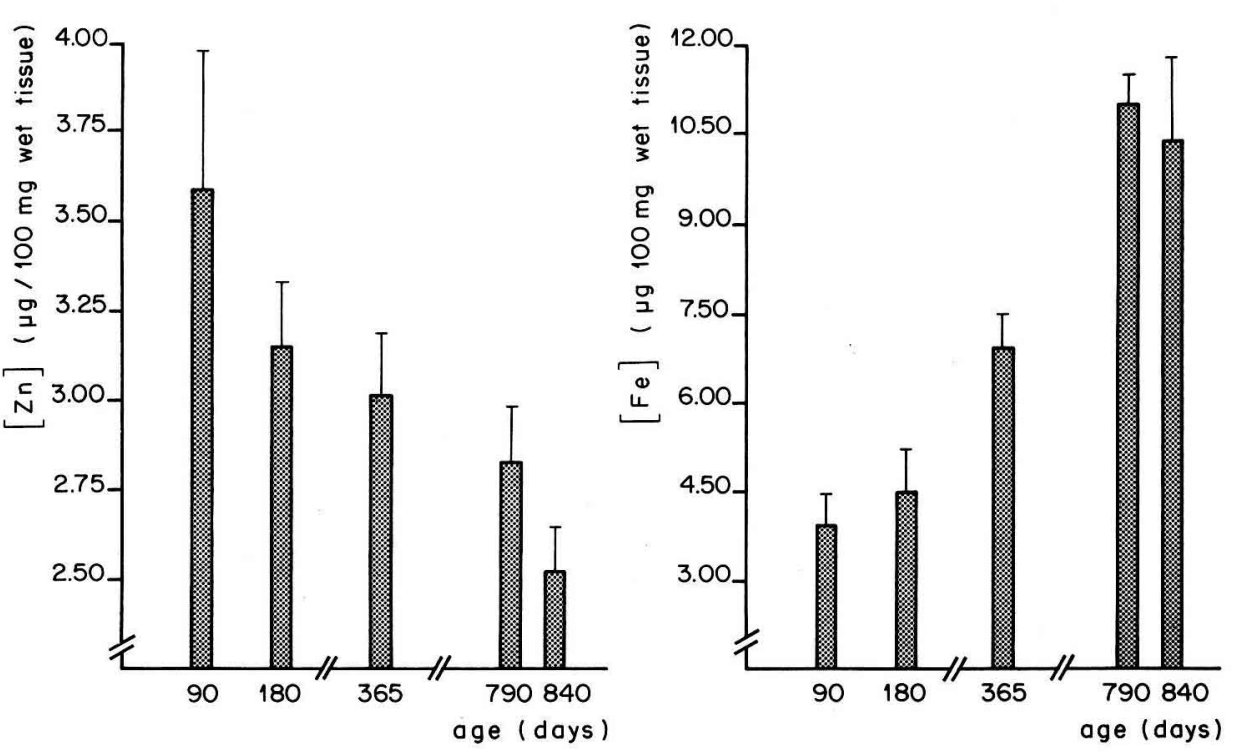

Effect of age on renal ionic concentration in the Fischer 344 rat.

FIG. 3. - Zinc.

FIG. 4. - Iron.

The effect of age on the concentration of renal iron is shown in figure 4. Between 90 and 740 days of age, there appeared to be a marked increase in the renal iron concentration. The lack of difference between the mean concentrations of 790 and 840 days of age might reflect the relatively small difference in age between these two ages.

The effect of age on the concentration of renal copper is shown in figure 5. No significant change was observed between 90 and 840 days of age. These data are unlike those on the heart (Baskin et al., 1979) or brain. 


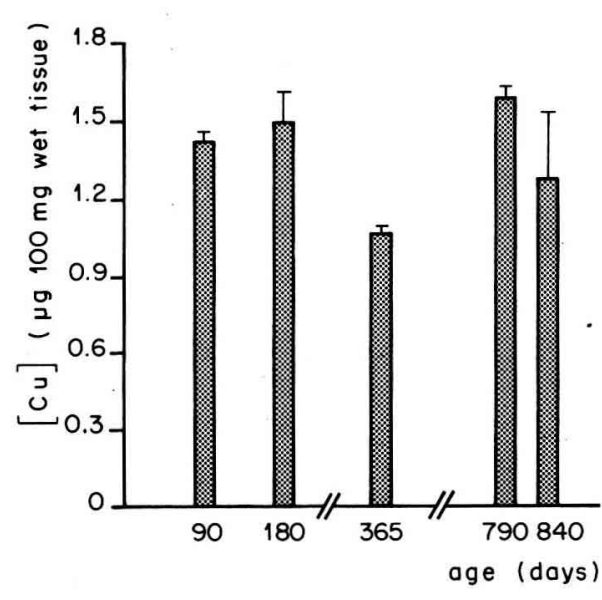

FIG. 5. - Effeci of age on renal copper concentration in the Fischer 344 rat.

\section{Discussion.}

Age-related differences in renal cation concentrations observed in this investigafion may affect functional changes reported in the kidney during aging (Goodman et al., 1979 ; Lowenstein, 1979). The five ions were selected for analysis because we wanted to compare the changes of those ions with age to earlier studies of ours examining the heart. We also attempted to compare the effect of age on manganese concentrations in the kidney. However, the concentration of that ion $(<0.025 \mu \mathrm{g} / \mathrm{ml})$ was below the detection limit of our methodology.

The reduction of magnesium with age might indicate a loss of enzymatic activity related to kinase-like enzymes (Baskin et al., 1979). Since these enzymes are directly linked to energy utilization, it is not surprising that the function of the tissues failed with those with less magnesium. This may be the case, particularly at 28 months ( 840 days).

It is unclear why there was no increase in total calcium, as seen from previous studies in the heart (Baskin ef al., 1979). Perhaps kidney mitochondria do not take up calcium in vivo to the same extent as the mitochondria of other tissues. Alternatively, other structures not present in the kidney, i.e. sarcoplasmic reticulum, are responsible for the increase in calcium observed in other tissues.

The loss of zinc in the kidney with age could be due to the loss of enzymatic binding sites with age, i.e. carbonic dehydrogenase. This may account for the diminished capacity of the kidney to maintain $\mathrm{HCO}_{3}{ }^{-}$control (Lowenstein, 1979).

The increase in renal iron might reflect a « rusting out » of the kidney. Since this effect was not seen in the other organs examined, it could be related to particular structures in the kidney, i.e. basement membranes (Kefalides et al., 1979). The accumulation of ions on the basement membranes, for example, may not allow for normal function and exchange of electrolytes. The « clogging » of the membrane sites with age may cause the functional diminution of the kidney, ultimately leading to the demise of the organism.

From 90 to 840 days of age, there was an inversely proportional relationship between the concentrations of zinc and iron. This relationship was linear between 180 
and 840 days of age. However, the data obtained at 90 days do not appear to be consistent, It is proposed that the altered ratio with the data seen at 90 days of age is due to developmental changes at that age.

The constant copper concentrations observed in the kidney with age suggest that homeostatic mechanisms regulate renal $\mathrm{Cu}$ throughout the life span of the animal (Friedan, 1968). The zinc : copper ratio found in the kidney decreased with age, which was unlike that which occurs in the heart with age (Baskin ef al., 1979). These varied ratios between organs might suggest that the regulation of these ions is tissuedependent. It may also be consistent with pathological changes believed to be related to only the vascular system (Klevay, 1980).

In summary, our data indicate that the ionic environment of the kidney changes with age. The changes observed could lead to modifications in enzymatic function which, in turn, might be manifested as pathological lesions of that organ. Thus, the changes in the ionic environment may lead to the viability of the organism.

Reçu en décembre 1980.

Accepté en avril 1981.

Acknowledgements. - The authors thank Drs. Jay Roberts, Barry Elkin and David Sawhill for their support of this project. The authors acknowledge the excellent secretarial assistance of Mary Montone. This project was funded in part by National Institutes of Health Grant AG00003 and CA22170.

Résumé. Il a été suggéré que la diminution de la fonction rénale avec l'âge pourrait être due à une plus faible concentration dans l'organe des ions indispensables ou à une accumulation d'ions susceptibles de provoquer une toxicité au niveau cellulaire. Dans le présent travail, l'effet de l'âge $(3,6,12,24$ et 28 mois) sur les concentrations en magnésium, calcium, zinc, cuivre et fer du rein a été étudié chez des rats de lignée Fischer 344. Les échantillons de tissu rénal étaient homogénéisés dans une solution contenant 5 p. 100 de La et 25 p. 100 de $\mathrm{NO}_{3} \mathrm{H}$. Les solutions obtenues après minéralisation et centrifugation ont été analysées par spectrophotométrie d'absorption atomique. En fonction de l'âge, le taux de magnésium décroît $(p<0,05)$, tandis que les concentrations de calcium et cuivre restent inchangées ; celle du zinc diminue légèrement, alors que celle du fer augmente de façon marquée $(p<0,05)$. En résumé, les présentes données et celles obtenues par des études similaires effectuées sur le cerveau et le cœur, montrent que les changements observés avec l'âge sont spécifiques du rein. Nos résultats suggèrent que les changements de concentrations des ions dans le rein avec l'âge, contribueraient à diminuer la fonction rénale phénomène observé à la sénescence.

\section{References}

BASKIN S. I., DUTTA S., MARKS B. H., 1973. The effect of diphenylhydantoin and potassium on the biological activity of ouabain in the guinea pig heart. Brit. J. Pharmacol., 47, 85-96.

BASKIN S. I., KENDRICK Z. V., AKERA T., YAMAMOTO S., BRODY T. M., 1979. The effect of digitalis on sodium, potassium-ATPase of myocardial and neural tissue, 281-291. In BOWDEN D. M., Aging in Nonhuman Primates. Van Nostrand Reinhold Publ.

BASKIN S. I., URICCHIO F. J., 1979. The effect of age on the regimal distribution of four cations in the rat heart. Age, 2, 64-67.

COLEMAN G. L., BARTHOLD S. W., OSBALDISTON G. W., FOSTER S. J., JONES A. M., 1977. Pathological changes during aging in barrier-reared Fischer 344 male rats. J. Gerontol., 32, 258-278. 
EPSTEIN F. H., SILVA P., 1974. Role of $\mathrm{Na}^{+}, \mathrm{K}^{+}$-ATPase in renal function. In ASKARI A., Properties and Functions of $\left(\mathrm{Na}^{+}+\mathrm{K}^{+}\right)$Activated Adenosine Triphosphotose. Ann. N. Y. Acad. Sci., 242, 519526.

FRIEDAN E., 1968. The biochemistry of copper. Sci. Am., 218, 103-114.

GOODMAN D. G., WARD J. M., SQUIRE R. A., CHU K. C., LINHART M. S., 1979. Neoplastic and non-neoplastic lesions in aging F344 rats. Toxicol. appl. Pharmacol., 48, 237-248.

KEFALIDES N. A., ALPER R., CLARK C. C., 1979. Biochemistry and metabolism of basement membranes. Int. Rev. Cytol., 61, 167-228.

KLEVAY L. M., 1980. Interactions of copper and zinc in cardiovascular disease, 241-251. In LEVANDER D. A., CHENG L., Micronutrient Interactions : Vitamins, Minerals, and Hazardous Elements. N. Y. Acad. Sci.

LOWENSTEIN L. M., 1979. The rat as a model for aging in the kidney, 235-242. In GIBSON D. C., ADELMAN R. C., FINCH C., Development of the Rodent as a Model System of Aging II. U.S. HEW NIH Publ.

SCHROEDER H. A., BALASSA J. J., VINTON W. H., 1965. Chromium, cadmium, and lead in rats : effects on life span, tumors, and tissue levels. J. Nutr., 86, 61-66.

WALSER M., 1967. Magnesium metabolism. Rev. Physiol. Biochem. exper. Pharmacol., 59, 184-341.

WEINER, 1971. Statistical Principles in Experimental Design, McGraw Hill, New York, 2nd Ed.

YUNICE A. A., PERRY E. F., PERRY H. M., 1968. Effect of desferrioxamine on trace metals in rat organs. Arch. environ. Health., 16, 163-170. 